\title{
Management of solitary fibrous tumors localized in extremity: case series and a review of the literature
}

\author{
Ekstremite yerleşimli soliter fibröz tümörlerin tedavisi: \\ Olgu serisi ve literatürün gözden geçirilmesi
}

\author{
Recep Öztürk, MD, Şefik Murat Arıkan, MD, Mehmet Akif Şimşek, MD, \\ Emre Özanlağan, MD, Bedii Şafak Güngör, MD \\ Department of Orthopaedics and Traumatology, \\ Dr. Abdurrahman Yurtaslan Ankara Oncology Training and Research Hospital, Ankara, Turkey
}

\begin{abstract}
Objectives: This study aims to evaluate the clinical characteristics and treatment results of patients with a diagnosis of solitary fibrous tumor localized in extremity.

Patients and methods: Clinical findings, treatment methods, clinical outcomes and treatment failures of seven patients ( 3 males, 4 females; mean age $49.7 \pm 20.7$ years; range 22 to 79 years) diagnosed as solitary fibrous tumor localized in extremity between January 2005 and December 2016 were evaluated retrospectively.
\end{abstract}

Results: Most frequent localization was the thigh (42.8\%, $\mathrm{n}=3$ ). Mean tumor size was $10.8 \pm 2.4 \mathrm{~cm}$ (range $8-15 \mathrm{~cm}$ ). All patients applied with painless mass and all had primary tumor. All patients had localized disease at the time of diagnosis. Postoperative mean follow-up duration was 44.4 months (range 13-121 months). Marginal resection was performed in two patients at low risk group while wide resection was performed in other patients at moderate and high risk groups. Patients who underwent marginal resection were performed adjuvant radiotherapy. No recurrence or metastasis was detected in any of the patients during follow-up.

Conclusion: In the treatment of solitary fibrous tumors localized in extremity, marginal resection together with radiotherapy may be an alternative treatment method for patients in low risk group according to risk stratification model, for whom wide resection is not possible. Wide resection is recommended in moderate and high risk groups to decrease local recurrence and metastasis risks.

Keywords: Hemangiopericytoma; limb salvage; radiotherapy; solitary fibrous tumor.

\section{ÖZ}

Amaç: $\mathrm{Bu}$ çalışmada ekstremite yerleşimli soliter fibröz tümör tanılı hastaların klinik özellikleri ve tedavi sonuçları değerlendirildi.

Hastalar ve yöntemler: Ocak 2005 - Aralık 2016 tarihleri arasında ekstremite yerleşimli soliter fibröz tümör tanısı konulan yedi hastanın (3 erkek, 4 kadın; ort. yaş 49,7 720,7 yıl; dağılım 22-79 yıl) klinik bulguları, tedavi yöntemleri, klinik sonuçları ve tedavi başarısızlıkları retrospektif olarak değerlendirildi.

Bulgular: En sık kitle yerleşim yeri uyluk idi $(\% 42,8, \mathrm{n}=3)$. Ortalama tümör boyutu $10,8 \pm 2,4 \mathrm{~cm}$ (dağ $111 \mathrm{~m} 8-15 \mathrm{~cm}$ ) idi. Tüm hastalar ağrısız kitle ile başvurdu ve tümünde primer tümör vardı. Tüm hastalar tanı anında yerleşik hastalığa sahipti. Ameliyat sonrası ortalama takip süresi 44,4 ay (dağılım 13-121 ay) idi. Düşük risk grubunda olan iki hastaya marjinal rezeksiyon, orta ve yüksek risk grubunda olan diğer hastalara geniş eksizyon uygulandı. Marjinal rezeksiyon geçiren hastalara adjuvan radyoterapi uygulandı. Hiçbir hastada takip sırasında nüks veya metastaz saptanmadi.

Sonuç: Ekstremite yerleşimli soliter fibröz tümörlerin tedavisinde risk stratifikasyon modeline göre düşük risk grubunda olup geniş rezeksiyonun mümkün olmadığ hastalarda marjinal rezeksiyon ile beraber radyoterapi alternatif bir tedavi yöntemi olabilir. Orta ve yüksek risk grubunda lokal nüks ve metastaz riskinin azaltılması için geniş rezeksiyon önerilmektedir.

Anahtar sözcükler: Hemanjiyoperisitom; uzuv kurtarma; radyoterapi; soliter fibröz tümör.

- Received: May 31, 2016 Accepted: November 03, 2016

- Correspondence: Recep Öztürk, MD. Dr. Abdurrahman Yurtaslan Ankara Onkoloji Eğitim ve Araștırma Hastanesi, Ortopedi ve Travmatoloji Kliniği, 06200 Yenimahalle, Ankara, Turkey. Tel: +90 505-4634794 e-mail: ozturk_recep@windowslive.com 
Solitary fibrous tumors (SFTs) are rare lesions stemmed from primitive fibroblast -like cells in connective tissue. ${ }^{[1]}$ Despite the fact that SFTs are localized to pleura and other serosal surfaces in general, they may nest in extrapleural soft tissues rarely. ${ }^{[2]}$

Extra-pleural SFTs account for $0.6 \%$ of all soft tissue tumors. ${ }^{[3]}$ Soft tissues of extremity are among the rarest site of occurrence; most occur in the proximal lower extremity and tend to have more malignant potential. ${ }^{[4]}$

Solitary fibrous tumors principally affect adults between the second and seventh decades of life (median 50 years). ${ }^{[1]}$ In general, SFTs are benign and good edged tumors. However, there may be $10-15 \%$ recurrence or metastases. SFTs in the extremities should be treated with local wide resection in patients without severe disability. If there are evidences that suggest malignant potential, wide resection together with a long-term follow-up and regular magnetic resonance imaging (MRI) controls are advised. ${ }^{[5]}$

Adjuvant radiotherapy and chemotherapy are recommended for metastases, recurrence and incomplete resection. ${ }^{[6]}$ In this study, we aimed to evaluate the clinical characteristics and treatment results of patients with a diagnosis of SFT localized in extremity.

\section{PATIENTS AND METHODS}

A total of seven patients ( 3 males, 4 females; mean age $49.7 \pm 20.7$ years; range 22 to 79 years) diagnosed as SFT in extremity at Ankara Oncology Training and Research Hospital between January 2005 and December 2016 were evaluated retrospectively. The study protocol was approved by Ankara Oncology Training and Research Hospital Ethics Committee. A written informed consent was obtained from each patient. The study was conducted in accordance with the principles of the Declaration of Helsinki.

Pathologic material was examined by an experienced soft tissue pathologist and scored for the presence of a histologically malignant component. According to the risk stratification model they published, Demicco et al..$^{[7]}$ defined recurrence/ metastasis risk in patients as low, medium, and high. Age, tumor size and mitotic figures are reviewed and scores are set as follows:

For age <55: 0 point, 255: 1 point; for size $(\mathrm{cm})<5 \mathrm{~cm}$ : 0 point, $5-10 \mathrm{~cm}: 1$ point, $10-15 \mathrm{~cm}$ : 2 points, $\geq 15 \mathrm{~cm}: 3$ points; for the mitotic figures (/10 high-power fields): 0 mitotic figure: 0 point, 1-3 mitotic figures: 1 point, $\geq 4$ mitotic figures: 2 points. And total scores are set as:

0-2: low malignancy risk, 3-4: moderate malignancy risk, and 5-6: high malignancy risk.

The history, physical examination, posteroanterior lung radiograms, thorax computed tomograms, MRI studies, angiograms and routine laboratory studies of all the patients were analyzed.

All patients were reviewed according to age at diagnosis, primary tumor localization, duration passed before diagnosis, symptoms and findings, size of the tumor, surgical procedure type (marginal excision or wide resection), microscopic surgical margins (inadequate surgical margin was defined as the tumor being $2 \mathrm{~mm}$ or closer to the marked margin), chemotherapy, radiotherapy and treatment failures (Table I).

\section{Statistical analysis}

All statistical analyses were performed using IBM SPSS 22.0 statistical software (IBM Corp., Armonk, NY, USA). Descriptive statistics are expressed as mean \pm standard deviation, frequency and percentage.

\section{RESULTS}

All patients applied with primary tumor and had localized disease at the time of diagnosis (Table I). The most frequent localization was anteromedial thigh $(42.8 \%, \mathrm{n}=3)$. There was one patient with

TABLE I

Patient characteristics, reconstruction types and surgical margins

\begin{tabular}{|c|c|c|c|c|c|c|c|c|}
\hline Case & $\begin{array}{l}\text { Age/Gender } \\
\text { (year) }\end{array}$ & Localization & Size $(\mathrm{cm})$ & $\begin{array}{l}\text { Duration before } \\
\text { (months) }\end{array}$ & Vascular involvement & Nerve infiltration & Resection type & $\begin{array}{l}\text { Microscopic } \\
\text { surgical margin }\end{array}$ \\
\hline 1 & 79/M & Calf & 15 & 1 & $\begin{array}{l}\text { Arteria, vena tibialis anterior } \\
\text { Arteria, vena fibularis }\end{array}$ & $\begin{array}{l}\text { Nervus peroneus } \\
\text { profundus }\end{array}$ & Wide resection & Negative \\
\hline 2 & $68 / F$ & Thigh & 12 & 12 & Arteria, vena femoralis & - & Wide resection & Negative \\
\hline 3 & $56 / F$ & Thigh & 8 & 6 & - & - & Wide resection & Negative \\
\hline 4 & $56 / \mathrm{M}$ & Poplitea & 11 & 12 & - & - & Wide resection & Negative \\
\hline 5 & $30 / F$ & Thigh & 8 & 18 & Arteria, vena femoralis & - & Marginal excision & Positive \\
\hline 6 & $37 / \mathrm{F}$ & Ankle & 7 and 5: 12 & 24 & - & - & Wide resection & Negative \\
\hline 7 & $22 / M$ & Knee & 10 & 7 & - & - & Marginal excision & Positive \\
\hline
\end{tabular}



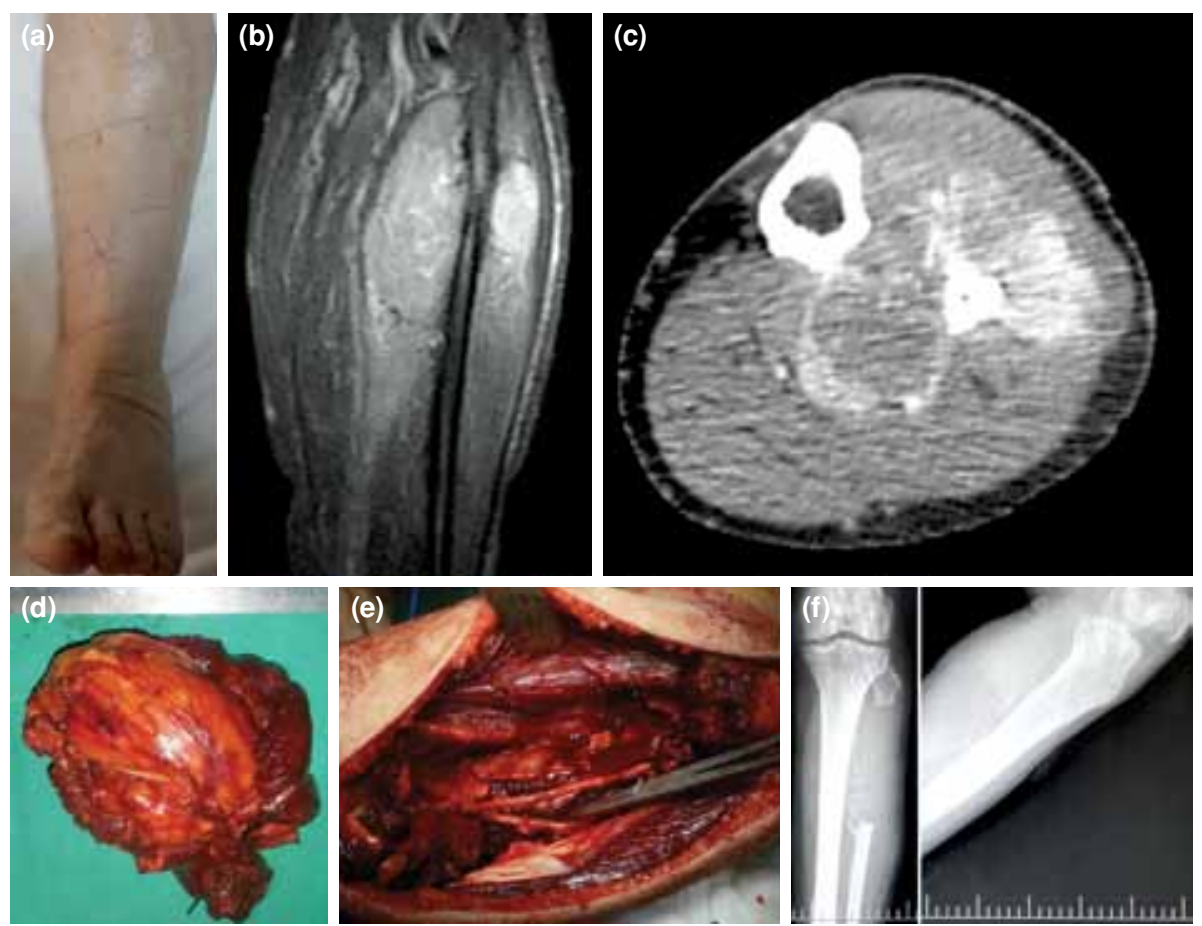

Figure 1. Proximal cruris solitary fibrous tumor. (a) Preoperative photography of extremity. (b) Preoperative magnetic resonance coronal T2 section. (c) Preoperative computed tomography. (d) Macroscopic image of pathologic material. (e) In tumor bed, tibialis posterior over clamp and nervus tibialis inferior under clamp after (f) postoperative X-ray (Case 1).

the tumor localized to medial knee $(14.2 \%)$, while one had tumor on proximal lateral cruris $(14.2 \%)$ (Figures 1-3).

All patients applied with a soft tissue tumor. Mean mass size was $10.8 \pm 2.4 \mathrm{~cm}$ (range $8-15 \mathrm{~cm}$ ). The time passed between the symptom onset and patient application was 11.4 months (range 1-24 months) (Table I).
All patients were diagnosed via incisional biopsy. According to risk stratification, two patients were at high risk group, three patients were at medium risk group, and two patients were at low risk group (Table II).

In three patients, the tumors were closely related to vessels and nerves. Among these, one patient in high risk group with tumor localized on
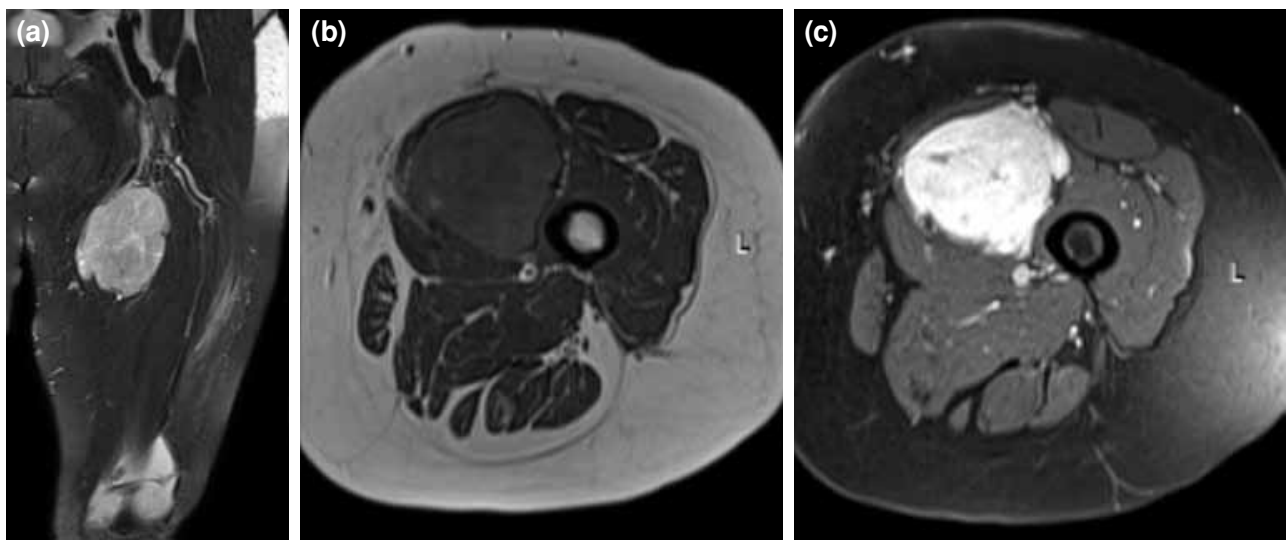

Figure 2. Solitary fibrous tumor on anteromedial thigh. (a) Preoperative magnetic resonance coronal $\mathrm{T}_{2}$ section. (b) Preoperative magnetic resonance axial $\mathrm{T}_{1}$ section. (c) Preoperative magnetic resonance axial $\mathrm{T}_{2}$ section (Case 2 ). 

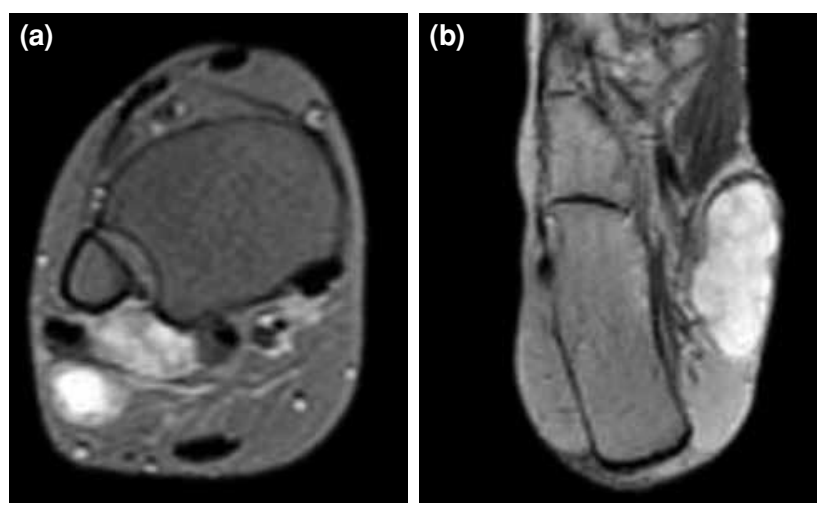

Figure 3. Solitary fibrous tumor on both medial and lateral of ankle. (a) Lateral tumor, magnetic resonance axial $\mathrm{T}_{2}$ section. (b) Magnetic resonance medial tumor axial $\mathrm{T}_{2}$ section (Case 6).

thigh (case 2) was performed femoral artery and femoral vein resections to establish wide resection. Saphenous vein calibration was not suitable for artery reconstruction, so polytetrafluoroethylene (PTFE) graft was administered. One patient in low risk group with tumor localized on thigh (case 5) was performed marginal excision by sparing femoral artery-vein bundles. For the patient in high risk group with tumor on proximal cruris (case 1), wide resection was performed with resection of arteria, vena, and nervus peroneus and arteria and vena tibialis anterior by sparing posterior tibial artery and tibialis posterior vein (Figure 1). Wide tumor resection was performed in other four patients.

All patients were consulted to medical oncology and radiation oncology clinics, and two patients who underwent marginal resection were also given radiotherapy. There was no chemotherapy indication for any patient (Table I).

The results of immunohistochemical staining were summarized in Table II. Histopathological evaluation belonging to SFT in thigh (case 5) was shown in Figure 4.
Chronic edema was seen in two patients (cases 1, 2), and those patients were followed-up with elevation and compression socks. One patient had acute hematoma and skin separation (case 5) and was applied hematoma drainage and suture. In one patient (case 1), foot drop was seen due to the sacrifice of peroneal nerve. Foot ankle orthosis was implanted in this patient, who tolerated it well (Table I).

After a mean postoperative follow-up period of 44 months (range 13-121 months), none of the patients had any evidence of local recurrence or distant metastasis. The follow-up and treatment of patients are still ongoing (Table II).

\section{DISCUSSION}

Solitary fibrous tumor is a pleural based rare tumor stemmed from mesenchymal cells. ${ }^{[8]}$ It is a vascular originated tumor just like hemangioma and hemangiopericytoma. ${ }^{[9]}$ Despite the fact that SFTs are localized to pleura and other serosal surfaces in general, they may nest in extrapleural soft tissues rarely. ${ }^{[2]}$ Extra-pleural SFT accounts for $0.6 \%$ of all soft tissue tumors. ${ }^{[3]}$ The World Health Organization has compiled extrapleural SFTs, hemangiopericytomas, lipomatous hemangiopericytomas and giant cell angiofibromas under extrapleural SFTs title in the classification of bone and soft tissue tumors. ${ }^{[10]}$

Curiously, soft tissues of extremity are among the rarest site of occurrence. Most occur in the proximal lower extremity and tend to have more malignant potential. ${ }^{[4]}$ In our study, the most frequent localization was thigh as well (42.8\%) and five of seven cases had malignant potential $(71.4 \%)$.

Solitary fibrous tumors principally affect adults between the second and seventh decades of life (median 50 years).$^{[1]}$ In the contemporary literature, there are patients that are out of this age interval (Table III). ${ }^{[1,12]}$ All patients in our study were also

TABLE II

Malignancy criteria, adjuvant chemotherapy, radiotherapy, follow-up and complications

\begin{tabular}{cccccccccc}
\hline Case & $\begin{array}{c}\text { Age } \\
\text { (year) }\end{array}$ & $\begin{array}{c}\text { Tumor size } \\
\text { (cm) }\end{array}$ & Mitosis & Total score & Risk & CT & $\begin{array}{c}\text { RT } \\
\begin{array}{c}\text { Follow-up } \\
\text { (month) }\end{array}\end{array}$ \\
\hline 1 & $\geq 55$ & $\geq 15$ & 3 & 5 & High & - & - & 21 & Extremity chronic edema, foot drop \\
2 & $\geq 55$ & 10 to $<15$ & $>4$ & 5 & High & - & - & 41 & Extremity chronic edema \\
3 & $\geq 55$ & 5 to $<10$ & 1 & 3 & Medium & - & - & 84 & - \\
4 & $\geq 55$ & 10 to $<15$ & 0 & 3 & Medium & - & - & 121 & - \\
5 & $<55$ & 5 to $<10$ & 1 & 2 & Low & - & + & 15 & Acute hematoma, skin separation \\
6 & $<55$ & 10 to $<15$ & 1 & 3 & Medium & - & - & 16 & - \\
7 & $<55$ & 10 to $<15$ & 0 & 2 & Low & - & + & 13 & -
\end{tabular}

CT: Chemotherapy; RT: Radiotherapy. 

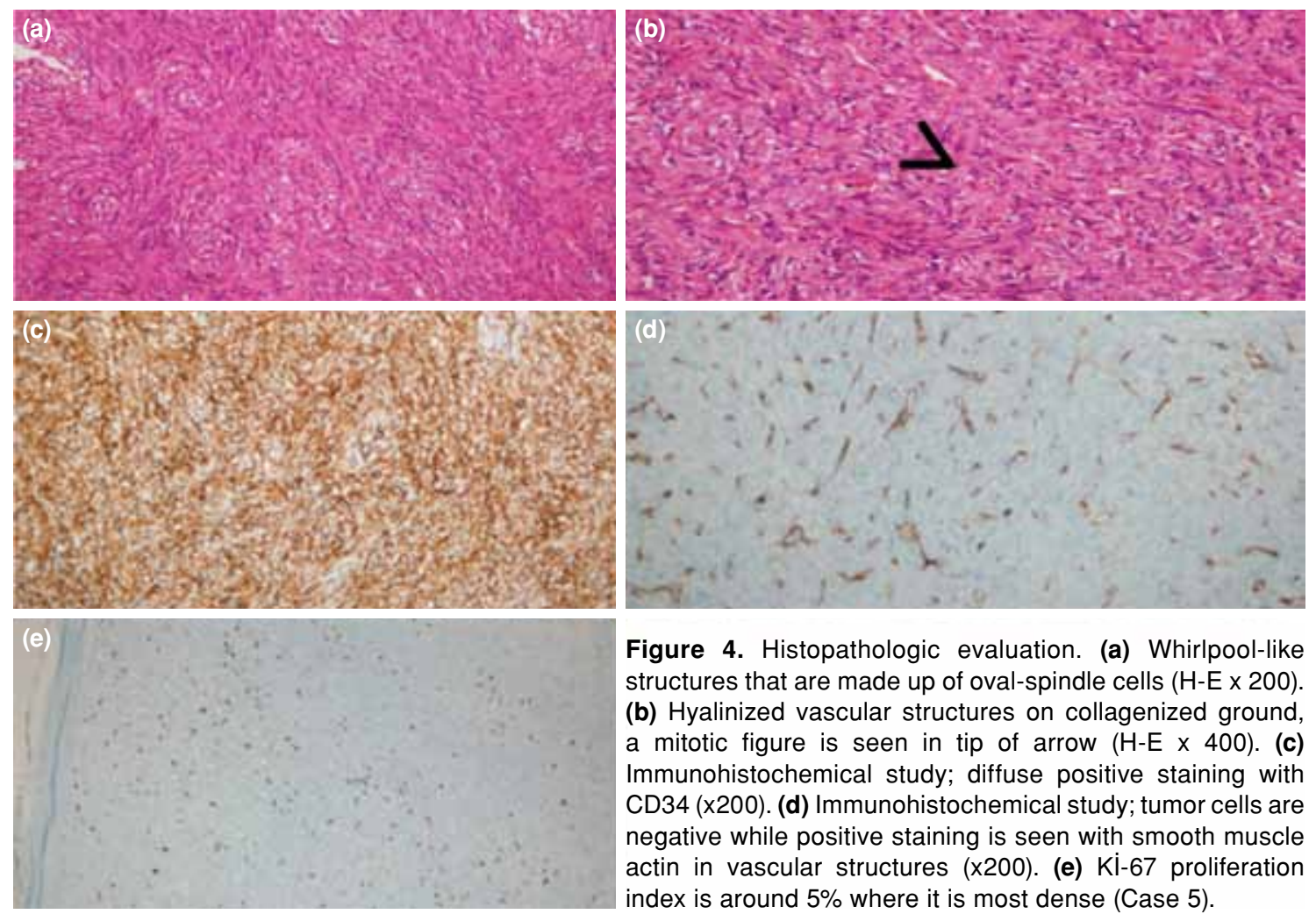

Figure 4. Histopathologic evaluation. (a) Whirlpool-like structures that are made up of oval-spindle cells (H-E x 200). (b) Hyalinized vascular structures on collagenized ground, a mitotic figure is seen in tip of arrow ( $\mathrm{H}-\mathrm{E} \times 400)$. (c) Immunohistochemical study; diffuse positive staining with CD34 (x200). (d) Immunohistochemical study; tumor cells are negative while positive staining is seen with smooth muscle actin in vascular structures (x200). (e) Ki-67 proliferation index is around $5 \%$ where it is most dense (Case 5 ).

between the mentioned age interval and the mean age was 49.7 years.

Symptoms related to extrapleural SFT are relatively nonspecific and related simply to the presence of a painless mass usually in deep soft tissue. ${ }^{[13]}$ Correspondingly, all patients in our study applied with painless mass complaint.

Imaging studies like plain radiography and ultrasound are nonspecific. In MRI study, focal and diffuse severe contrast agent uptake may be seen since the tumor may have regions that are quite vascularized. However, radiologic findings alone can not differentiate between malignant or benign tumors certainly and immunohistochemical analysis is needed to confirm the diagnosis. ${ }^{[14]}$

The microscopic findings of SFTs are nonspecific. Tumor cells generally possess fibroblastic and myofibroblastic differentiation. ${ }^{[15]}$ Typical SFT has an irregular architecture containing various amounts of hypocellular and hypercellular areas that are rich of thick, hyalinized, branched vascular structures. Tumor cells are not atypical in general. Cellularity is changeable and mitosis is seen rarely.

TABLE III

Literature review

\begin{tabular}{|c|c|c|c|c|c|}
\hline Authors/references & Localization & Mean age & Treatment & Follow-up (month) & Recurrence- complications \\
\hline Anders et al. ${ }^{[5]}$ & Thigh & 41 & Wide excision & 54 & - \\
\hline Thanni[6] $^{[6]}$ & Proximal cruris & 22 & En-bloc resection plus radiotherapy & 9 & Wound infection \\
\hline Fukui et al. ${ }^{[10]}$ & 1 shoulder 1 thigh & $81-70$ & Wide excision & $24-9$ & - \\
\hline Wan et al. ${ }^{[1]}$ & 3 thigh 1 calf & 47.8 & Wide excision & 65.5 & - \\
\hline Chandanwale et al. ${ }^{[11]}$ & Calf & 15 & Wide excision & 12 & Recurrence (12 month) \\
\hline Al-Shanawani et al. ${ }^{[20]}$ & Arm & 30 & Wide excision & 36 & - \\
\hline Yoshimura et al. ${ }^{[18]}$ & Thigh & 31 & Wide excision & 28 & $\begin{array}{l}\text { Recurrence (11 month) } \\
\text { Metastasis (19 month) }\end{array}$ \\
\hline Present study & $\begin{array}{l}3 \text { thigh } 1 \text { knee } 1 \text { calf } \\
1 \text { ankle } 1 \text { popliteus }\end{array}$ & 49.7 & $\begin{array}{c}2 \text { marginal excision plus } \\
\text { radiotherapy, } \\
5 \text { wide excision }\end{array}$ & 44.4 & $\begin{array}{c}2 \text { chronic edema, } 1 \text { acute } \\
\text { hematoma, skin separation, } \\
1 \text { drop foot }\end{array}$ \\
\hline
\end{tabular}


Malignant tumors are typically hypercellular and contain prominent atypicality, necrosis, too many mitosis ( $\geq 4 / 10$ high power field) and irregular infiltrative margins. ${ }^{[15]}$

In immunohistochemical evaluation, tumor cells are characteristically immunoreactive with CD34, vimentin and CD99.[16] Variably positive reaction is seen with epithelial membrane antigen, $\mathrm{Bcl} 2$, and smooth muscle actin. Limited and focal reactivity with S-100 protein, cytokeratin, and desmin has been announced. ${ }^{[16]} \mathrm{Ki}-67$ proliferation index may be useful for determining prognosis in the evaluation of malignant SFTs. ${ }^{[17]}$

Recent molecular studies have shown that 12q13 inversion leading to NAB2-STAT6 fusion is present in most cases. ${ }^{[18]}$

Two types of malignant transformation have been reported; the first is the malignant or highgrade transformation from benign, low-grade, or intermediate-grade SFTs, and the second is the de novo occurrence of malignant SFTs. ${ }^{[19]}$

Immunohistochemical patterns and some clinical indicators are used in therapeutic decisions for SFTs. According to a risk stratification model, recurrence/ metastasis risk in patients was defined as low, medium, and high. ${ }^{[7]}$ Other prognostic factors are positive surgical margin and tumor size (tumor size $\geq 10 \mathrm{~cm}$ ). ${ }^{[3]}$

In our study, two patients were at high risk, three patients were at medium risk and two patients were at low risk groups according to histopathologic risk stratification model (Table II).

Solitary fibrous tumors in the extremities should be treated with local wide resection in patients without severe disability. If there are evidences that indicate malignant potential, wide resection together with a long-term follow-up and regular MRI controls are suggested. ${ }^{[5]}$ Recently, authors published 10 patients in whom they implemented surgical treatment and found recurrence in two patients and metastasis in one patient in spite of resection with wide margins (Table III). ${ }^{[1,5,11,12,19,20]}$

In malignant tumors, common indications for amputation are major neurovascular involvement and large primary tumor where resection would leave a functionally useless limb. ${ }^{[21]}$

In our study, there were involvements of femoral artery-vein in case 5 and of medial collateral ligament in case 7. There was low malignancy risk for both cases according to risk stratification model. Marginal excision was performed for these two cases, while wide resection was performed in five cases possessing malignant potential.

Adjuvant radiotherapy and chemotherapy are recommended for metastases, recurrence and incomplete resection. ${ }^{[6]}$ Thanni ${ }^{[6]}$ has published a case in which radiotherapy was applied after en bloc resection (Table III). Two patients who underwent marginal excision in our study were applied radiotherapy (Table II).

Wide resection can be performed by means of en bloc resection in limb-sparing surgery for various malignant soft tissue tumors which are related to main vascular structures. Arterial or arteriovenous reconstruction (autologous or synthetic graft) is conducted to maintain blood flow after en bloc resection. ${ }^{[2]}$ When ipsilateral vena saphena magna, deep femoral vein junction and perigeniculate collaterals are protected, ligation of deep femoral vein does not cause any significant vascular complication. ${ }^{[23]}$

In our study, in the patient who had SFT possessing malignant characteristics on anteromedial thigh (case 2), femoral artery and femoral vein resections were performed in order to make wide excision. Saphenous vein calibration was not suitable for artery reconstruction, so femoropopliteal PTFE bypass was conducted. Reconstruction of femoral vein could not be performed, chronic edema was seen after femoral vein ligation.

Postoperative complications are rarely seen. Wound infection was described for a case in the acute period recently (Table III). ${ }^{[6]}$ Postoperative complications in our study included chronic edema in two patients (cases 1, 2), and those patients were followed-up with elevation and compression socks. One patient had acute hematoma and skin separation (case 5), for whom hematoma drainage and suture were applied. In one patient (case 1), foot drop was seen because of sacrifice of peroneal nerve. Foot ankle orthosis was implanted to this patient, who tolerated it well. Deep venous thrombosis complication was not seen in any patients at follow-up.

The present study has several limitations. It was designed as a retrospective study, and the number of patients was limited due to the fact that the disease in question are observed rarely. The same problem occurred in other studies, as well. A multicenter study may be required to obtain a larger population.

In conclusion, in the treatment of SFT localized in extremity, marginal resection together with radiotherapy may be an alternative treatment 
method for low risk group patients according to risk stratification model, for whom wide resection is not possible. Wide resection is suggested for moderate and high risk groups to decrease recurrence and metastasis risks.

\section{Declaration of conflicting interests}

The authors declared no conflicts of interest with respect to the authorship and/or publication of this article.

\section{Funding}

The authors received no financial support for the research and/or authorship of this article.

\section{REFERENCES}

1. Wan S, Ning L, Hong R, Wu W, Fan S, Tsuchiya H, et al. Clinicopathological features of solitary fibrous tumours in the extremities: four case reports and a literature review. J Int Med Res 2010;38:694-704.

2. Kim DH, Lim JS, Han KT, Kim MC. Giant Extrapleural Solitary Fibrous Tumor of the Thigh. Arch Plast Surg 2015;42:489-92.

3. Gold JS, Antonescu CR, Hajdu C, Ferrone CR, Hussain $\mathrm{M}$, Lewis JJ, et al. Clinicopathologic correlates of solitary fibrous tumors. Cancer 2002;94:1057-68.

4. Atik OŞ, Bozkurt HH, Özcan E, Bahadır B, Uçar M, Öğüt B, et al. Localized pigmented villonodular synovitis in a child knee. Eklem Hastalik Cerrahisi 2017;28:46-9.

5. Anders JO, Aurich M, Lang T, Wagner A. Solitary fibrous tumor in the thigh: review of the literature. J Cancer Res Clin Oncol 2006;132:69-75.

6. Thanni LO. Extremity haemangiopericytoma, a case report from Nigeria. Afr Health Sci 2005;5:261-4.

7. Demicco EG, Park MS, Araujo DM, Fox PS, Bassett RL, Pollock RE, et al. Solitary fibrous tumor: a clinicopathological study of 110 cases and proposed risk assessment model. Mod Pathol 2012;25:1298-306.

8. Musyoki FN, Nahal A, Powell TI. Solitary fibrous tumor: an update on the spectrum of extrapleural manifestations. Skeletal Radiol 2012;41:5-13.

9. Atalar H, Armangil M, Uzüm N, Sağlık Y. Solitary epithelioid hemangioendothelioma of the metacarpal. Eklem Hastalik Cerrahisi 2013;24:182-6.

10. Guillou L, Fletcher JA, Fletcher CDM, Mandahl N. Extrapleural solitary fibrous tumour and hemangiopericytoma. In: Fletcher CDM, Unni KK, Mertens F, editors. Pathology and genetics of tumours of soft tissue and bone. Lyon: IARC Press; 2002. p. 86-90.
11. Fukui T, Kavaguchi $Y$, Kawamoto T, Hitora T, Yamamoto T, Akusie T, et al. Solitary fibrous tumor arising in extremity: A report of two cases with 201-Thallium Scintigraphic and PET findings. Cancer Therapy 2008;6:1017-22.

12. Chandanwale SS, Gore CR, Sammi AB, Shah KR, Kaur PR: Recurrent solitary fibrous tumor in distal lower extremity: An extremely rare entity. Int J Appl Basic Med Res 2014;4:134-6.

13. Abe S, Imamura $T$, Tateishi A, Park $P$, Nakano $H$, Harasawa A, et al. Intramuscular solitary fibrous tumor: a clinicopathological case study. J Comput Assist Tomogr 1999;23:458-62.

14. Atik OŞ. Do not treat the radiograph, treat the patient! Eklem Hastalik Cerrahisi 2015;26:125.

15. Thway K, Ng W, Noujaim J, Jones RL, Fisher C. The Current Status of Solitary Fibrous Tumor: Diagnostic Features, Variants, and Genetics. Int J Surg Pathol 2016;24:281-92.

16. Hasegawa T, Matsuno Y, Shimoda T, Hasegawa F, Sano T, Hirohashi S. Extrathoracic solitary fibrous tumors: their histological variability and potentially aggressive behavior. Hum Pathol 1999;30:1464-73.

17. Sun $Y$, Naito Z, Ishiwata $T$, Maeda S, Sugisaki $Y$, Asano G. Basic FGF and Ki-67 proteins useful for immunohistological diagnostic evaluations in malignant solitary fibrous tumor. Pathol Int 2003;53:284-90.

18. Mohajeri A, Tayebwa J, Collin A, Nilsson J, Magnusson $\mathrm{L}$, von Steyern FV, et al. Comprehensive genetic analysis identifies a pathognomonic NAB2/STAT6 fusion gene, nonrandom secondary genomic imbalances, and a characteristic gene expression profile in solitary fibrous tumor. Genes Chromosomes Cancer 2013;52:873-86.

19. Yoshimura $Y$, Sano $K$, Isobe $K$, Aoki K, Kito M, Kato H. A recurrent solitary fibrous tumor of the thigh with malignant transformation: A case report. Int J Surg Case Rep 2016;21:111-4.

20. Al-Shanawani BN, Al-Qattan MM, Arafah MM, Al-Motairi MI. A solitary fibrous tumor of the upper limb. Saudi Med J 2015;36:236-8.

21. Ramamurthy $\mathrm{R}$, Soundrarajan JC, Mettupalayam V, Shanmugham S, Arumugam B, Periasamy S. Limb conservation in extremity soft tissue sarcomas with vascular involvement. Indian J Orthop 2009;43:403-7.

22. Ghert MA, Davis AM, Griffin AM, Alyami AH, White L, Kandel RA, et al. The surgical and functional outcome of limb-salvage surgery with vascular reconstruction for soft tissue sarcoma of the extremity. Ann Surg Oncol 2005;12:1102-10.

23. Adelani MA, Holt GE, Dittus RS, Passman MA, Schwartz HS. Revascularization after segmental resection of lower extremity soft tissue sarcomas. J Surg Oncol 2007;95:455-60. 